\title{
ARTICLE
}

Cite this: DOI: $10.1039 / \times 0 \times x 00000 x$

\section{Redox-Mediated Dissolution of Paramagnetic Nanolids to Achieve Smart Theranostic System}

\author{
Aifei Wang, ${ }^{\mathrm{a}}$ Mingyi Guo, ${ }^{\mathrm{a}, \mathrm{e}}$ Nan Wang, ${ }^{\mathrm{c}}$ Jianyun Zhao, ${ }^{\mathrm{d}}$ Wenxiu Qi, ${ }^{\mathrm{d}}$ Faheem \\ Muhammad, ${ }^{\mathrm{d}}$ Liang Chen, ${ }^{\mathrm{c}}$ Yingjie Guo, ${ }^{\mathrm{d}}$ Nam-Trung Nguyen ${ }^{\mathrm{b}}$ and Guangshan \\ $\mathrm{Zhu}^{* \mathrm{a}, \mathrm{b}}$
}

Received 00th January 2012,

Accepted 00th January 2012

DOI: $10.1039 / \times 0 \times x 00000 x$

Manganese oxide $\left(\mathrm{Mn}_{3} \mathrm{O}_{4}\right)$ nanoparticles have recently emerged as promising T1 contrast agent. In this study, for the first time, we demonstrated an interaction of $\mathrm{Mn}_{3} \mathrm{O}_{4}$ with biological system, and found a redox sensitive behavior of these paramagnetic nanoparticles in intracellular reducing environment. Inspired by these findings, we for the first time used this interaction for some therapeutic advantages and designed a versatile mesoporous silica based nanotheranostic system to realize redox-activated enhanced magnetic resonance imaging and responsive anticancer drug delivery. Contrary to previous reports, we firstly prepared high quality amine terminated hydrophilic $\mathrm{Mn}_{3} \mathrm{O}_{4}$ nanolids, without using multistep ligand exchange strategies. The resulting water stable and small-sized $\mathrm{Mn}_{3} \mathrm{O}_{4}$ nanolids were subsequently used as nanolids to cap drug loaded nanochannels of porous carrier. Exposure to highly prevalent intracellular reducing environment resulted in the steady-state dissolution of these nanolids and attained an intelligent drug release. Furthermore, the redox receptive dissolution of paramagnetic $\mathrm{Mn}_{3} \mathrm{O}_{4}$ nanolids into $\mathrm{Mn}^{2+}$ in turn increases the $\mathrm{T} 1$ signal to twofold, providing an added opportunity to even track the feedback of therapy. This study, in addition to simultaneously realizing drug delivery and imaging, also provides a new insight into the fate and interaction of manganese oxide nanoparticles with components of biological systems.

\section{Introduction}

Nanoparticle based therapeutics obviously has an intrinsic potential to bring a major shift in the landscape of the pharmaceutical industry. ${ }^{1-3}$ Evidently, scores of nanobased medicine have been approved by the US Food and Drug Administration (FDA) for clinical use, and many more are in clinical or preclinical pipelines. ${ }^{4,5}$ Liposomes, ${ }^{6}$ polymers, ${ }^{7}$ dendrimers, ${ }^{8}$ carbon nanotubes, ${ }^{9}$ gold ${ }^{10}$ and magnetic nanoparticle11 based therapeutics are few of the widely explored nanocarriers to increase the efficacy of various anticancer drugs due to enhanced permeability and retention (EPR) effect of cancer tissues. Furthermore, different pathophysiological conditions and ligand carrying capabilities of nanocarriers also ensured target specific intratumoral drug accumulation. Among these libraries of sophisticated nanocarriers, mesoporous silica nanoparticles (MSN) have recently emerged as a promising nanoplatform to engineer a wide array of therapeutic and diagnostic nanoconstructs. ${ }^{12,13}$

In particular, considering the stimuli responsive drug delivery, mesoporous silica has proved its niche in this realm, due to the presence of well-defined nanochannels and outer surface which can be manipulated to accommodate different environmental conditions. Using this concept of gate keeping, several research groups have attempted to design different stimuli responsive nanosystem to inhibit the premature release of cytotoxic drugs. To manipulate diverse kinds of capping entities, both external and internal triggers such as $\mathrm{pH},{ }^{14-16}$ redox, ${ }^{17-20}$ light, ${ }^{21,} 22$ enzymes, ${ }^{23}$ magnetic,${ }^{24}$ electric field and competitive binding, ${ }^{25}$ have been employed to regulate the release of cytotoxic molecules according to environmental requirements. In this respect, our group has recently reported a $\mathrm{pH}$ responsive nanovehicle by use of the acid sensitive nature of $\mathrm{ZnO}$ quantum dots to release an anticancer drug from mesopores. ${ }^{26}$

Besides stimuli responsive drug delivery, there has also been an overwhelming research interest in the development of theranostic nanomaterials for simultaneous imaging and therapy. In view of that, diverse kinds of biological imaging agents have been incorporated into mesoporous silica, to realize X-ray computed tomography $(\mathrm{CT})^{27}$, fluorescence, ${ }^{28}$ near IR (NIR)29, and magnetic resonance imaging (MRI). ${ }^{30-32}$ Currently, MRI is one of the most dominant in vivo imaging technologies; however clinically, to improve the quality of 
image, contrast enhancement agents are used to increase the signal difference between the area of concern and the background. In the last few years, Hyeon's research group reported several studies that incorporated MRI agents into mesoporous silica. ${ }^{33-35}$ Recently, they have fabricated a core shell MnO@MSN nanostructure for labelling stem cells. ${ }^{35}$ Very recently, manganese oxides based nanoparticles has been developed as T1 contrast agents for MRI signal enhancement ${ }^{36}$, 37

Despite this phenomenal research activity in nanotheranostics, more specific and precise manipulation are needed to not only achieve stimuli responsive drug release, but also improve the quality of imaging for better diagnosis or subsequent feedback of chemotherapy. Till now, numerous redox responsive systems have been developed for intracellular release of several therapeutic entities, by using widely known reducing agents such as dithiothreitol (DTT), mercaptoethanol and glutathione (GSH). ${ }^{17,18}$ Mechanistically, the cleavage of disulphide bond has been a sole option in all previously reported redox responsive system to uncap the nanochannels.

Through a paramagnetic nanolid dissolution strategy, instead of disulphide bond cleavage, herein we developed an intelligent dual-purpose nanocarrier to achieve both simultaneous therapy and MRI. The paramagnetic nanocrystals $\left(\mathrm{Mn}_{3} \mathrm{O}_{4}\right)$ have been demonstrated to disintegrate in response to intracellular redox trigger GSH. Exposure of drug loaded $\mathrm{Mn}_{3} \mathrm{O}_{4} @ \mathrm{MSN}$ nanoformulation to glutathione resulted in the dissolution of $\mathrm{Mn}_{3} \mathrm{O}_{4}$ nanolids, thus releasing the drug molecules from MSN (functioning mechanism is illustrated in Fig. 1). Moreover, mesoporous surface tethered redox-sensitive $\mathrm{Mn}_{3} \mathrm{O}_{4}$ nanocrystals simultaneously served as nanolids and provided an opportunity for enhanced MR images due to the presence of free $\mathrm{Mn}(\mathrm{II})$ ions released after the dissolution of nanolids.

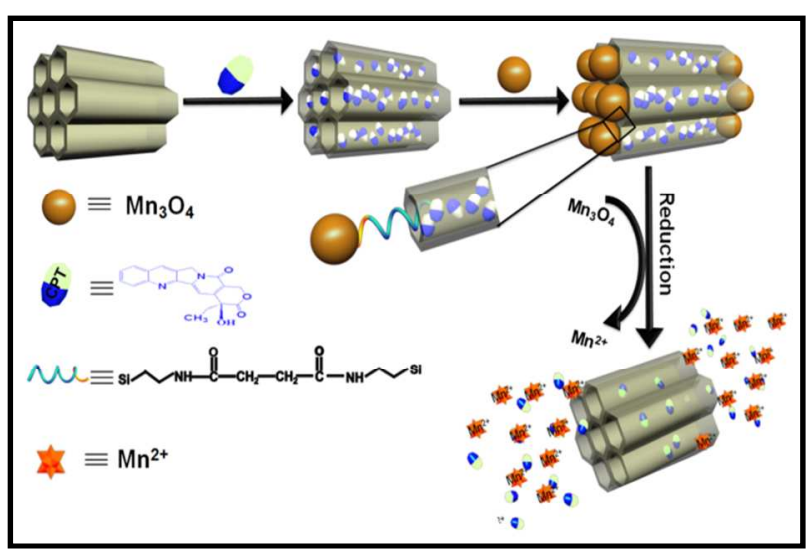

Fig. 1 Schematic illustration of the synthesis of $\mathrm{Mn}_{3} \mathrm{O}_{4}$ paramagnetic nanocrystals capped MSN and intracellular redox trigger release of the anticancer Drug (camptothecin) from MSN.

\section{Experimental}

\subsection{Materials and instrumentation}

Cetyltrimethylammonium

bromide

(CTAB), tetraethylorthosilicate (TEOS), 3-Aminopropyltriethoxysilane (APTES), 1-(3-(dimethylamino)propyl)-3-ethylcarbodiimide hydrochloride (EDC $\cdot \mathrm{HCl})$, Camptothecin $(\mathrm{CPT})$, Glutathione (GSH) and Dithiothreitol (DTT) were purchased from Aladdin Reagent Company. 3-[4,5-dimethylthialzol-2-yl]-2,5diphenyltetrazolium bromide (MTT) was purchased from Sigma-Aldrich. The morphologies and detailed structure of the samples were recorded using JEOL JSM-6700F field-emission scanning electron microscope (SEM) and FEI Tecnai G2 F20 S-TWIN transmission electron microscope (TEM). The powder XRD patterns were recorded on a Rigaku D/Ma 2550 X-ray diffractometer with $\mathrm{Cu}-\mathrm{K} \alpha$ radiation $(\lambda=1.5418 \AA)$. Fourier transform infrared (FTIR) spectra were collected on a Nicolet Impact 410 FTIR spectrometer in the range of $400-4000 \mathrm{~cm}-1$. Elemental analysis was carried out on Perkin-Elmer ICP-OES Optima 3300DV. X-ray photoelectron spectroscopy (XPS) was performed using an ESCALAB 250 spectrometer. Raman spectra were obtained with a Renishaw Raman system model 1000 spectrometer.

\subsection{Synthesis of water dispersible $\mathrm{Mn}_{3} \mathrm{O}_{4}$ nanocrystals}

$\mathrm{Mn}_{3} \mathrm{O}_{4}$ nanocrystals were synthesized by a facile hydrothermal method, using $\mathrm{Mn}\left(\mathrm{CH}_{3} \mathrm{COOH}\right) 2 \cdot 4 \mathrm{H}_{2} \mathrm{O}$ as manganese source. First of all, $\mathrm{Mn}\left(\mathrm{CH}_{3} \mathrm{COOH}\right)_{2} \cdot 4 \mathrm{H}_{2} \mathrm{O}(10 \mathrm{mmol})$ was dissolved in $70 \mathrm{~mL} \mathrm{~N}, \mathrm{~N}$-dimethylformamide (DMF). Then, the transparent solution was transferred into Teflon-lined autoclave and heated at $160{ }^{\circ} \mathrm{C}$ for $8 \mathrm{~h}$, cooled down to room temperature naturally. After the synthesis of $\mathrm{Mn}_{3} \mathrm{O}_{4}$ nanocrystal, they were rendered water soluble by functionalization with amine moiety. The assynthesized transparent solution of $\mathrm{Mn}_{3} \mathrm{O}_{4}$ was transferred into a round bottom flask and temperature was raised to $130{ }^{\circ} \mathrm{C}$, followed by the addition of $500 \mu \mathrm{L}$ of APTES. The resulting brownish precipitate was afterwards centrifuged and washed with ethanol, dried in air.

\subsection{Synthesis and modification of MSN}

MSN was prepared as described previously. $0.5 \mathrm{~g}$ of CTAB was first dissolved in $240 \mathrm{~mL}$ deionized water. Sodium hydroxide aqueous solution $(2 \mathrm{M}, 1.8 \mathrm{~mL})$ was added to the CTAB solution, and then the reaction temperature was raised to $80^{\circ} \mathrm{C}$. After stabilizing the temperature, TEOS $(2.5 \mathrm{~mL}, 11.2 \mathrm{mmol})$ was added drop wise to the surfactant solution and held the reaction mixture for $2 \mathrm{~h}$ to give a white precipitate. The solid product was filtered, washed with deionized water and ethanol, dried at $60{ }^{\circ} \mathrm{C}$ to yield the as-synthesized MSN. The surface of as-synthesized MSN was functionalized with carboxyl groups to ensure capping by treatment as follows. As-synthesized MSN (300 mg) was refluxed for $12 \mathrm{~h}$ in $20 \mathrm{~mL}$ anhydrous toluene, containing $300 \mu \mathrm{L}$ APTES, to functionalize amine group. After centrifugation and washing with ethanol, aminefunctionalized MSN was redispersed in $20 \mathrm{~mL}$ of DMSO with succinic anhydride $(100 \mathrm{mg})$ and triethylamine $(100 \mu \mathrm{L})$ and stirred at $50{ }^{\circ} \mathrm{C}$ for $24 \mathrm{~h}$ to yield the MSN-COOH. To remove the template (CTAB), the MSN-COOH was refluxed for $6 \mathrm{~h}$ in acidic methanolic solution. 


\subsection{Loading, capping and release experiments}

Typically, blank MSN-COOH powder (50 mg) was dispersed into $1 \mathrm{~mL}$ DMSO, containing $10 \mathrm{mg} \mathrm{CPT}$, and stirred at room temperature for overnight to load hydrophobic drug. The solution was then centrifuged and dispersed in water and further stirred for $6 \mathrm{~h}$, followed by addition of $25 \mathrm{mg} \mathrm{EDC} \cdot \mathrm{HCl}$ and $200 \mathrm{mg} \mathrm{Mn}_{3} \mathrm{O}_{4}$ nanocrystals (dispersed in water). The mixture was stirred for another $10 \mathrm{~min}$. The precipitate was centrifuged, it was then dialyzed (molecular weight cut-off $=8$ $\mathrm{kDa}$ ) against distilled water for 2 days to remove the CPT from uncapped nanochannels. All the washings including before capping were collected to calculate the final loading amount. To investigate the redox-responsive properties of $\mathrm{Mn}_{3} \mathrm{O}_{4} @ \mathrm{MSN} @ \mathrm{CPT}$ formulation, $5 \mathrm{mg}$ sample was first dispersed in $5 \mathrm{~mL}$ of PBS with different concentration of GSH or DTT, then put in a dialysis bags and dialyzed against $45 \mathrm{~mL}$ of respective solutions in outside vial. The released quantity of CPT was collected at predetermined time intervals and analyzed by UV/Vis spectroscopy at $365 \mathrm{~nm}$.

\subsection{Cell culture and in vitro cell viability assay}

Pancreatic cancer cells (BxPC-3) were grown in monolayer in Dulbecco's Modified Eagle's Medium (DMEM, Gibco) supplemented with $5 \%(\mathrm{v} / \mathrm{v})$ fetal bovine serum (FBS, Gibco) and penicillin/streptomycin $(100 \mathrm{U} / \mathrm{ml}$ and $100 \mu \mathrm{g} / \mathrm{ml}$, respectively, Gibco) in a humidified $5 \% \mathrm{CO}_{2}$ atmosphere at $37{ }^{\circ} \mathrm{C}$. Cell viability was investigated by measuring the ability of cells to transform MTT to a purple formazan dye. For MTT assay, BxPC-3 cells were seeded into 96-well plates at a density of $8^{*} 10^{3}$ cells per well in $100 \mu \mathrm{L}$ of media and grown overnight The cells were then incubated with various $\left[\mathrm{Mn}^{2+}\right]$ concentrations of $\mathrm{MnCl}_{2} \cdot 4 \mathrm{H}_{2} \mathrm{O}, \mathrm{Mn}_{3} \mathrm{O}_{4}, \mathrm{MSN}-\mathrm{COOH}$, $\mathrm{Mn}_{3} \mathrm{O}_{4} @ \mathrm{MSN} @ \mathrm{CPT}$ and the corresponding concentrations of free CPT. After incubation for $72 \mathrm{~h}, 10 \mu \mathrm{L} /$ well of MTT solution $(5 \mathrm{mg} / \mathrm{L}$ phosphate buffered saline) was added for another $4 \mathrm{~h}$. The precipitated formazan violet crystals were dissolved in $100 \mu \mathrm{L}$ of $10 \%$ SDS in $10 \mathrm{mmol} \mathrm{HCl}$ solution at $37{ }^{\circ} \mathrm{C}$ overnight. The colour intensity of the formazan solution, which reflects the cell growth condition, was measured at 570 $\mathrm{nm}$ by multi-detection microplate reader (SynergyTM HT, BioTek Instruments, USA).

\subsection{In vitro and in vivo MR Imaging}

The T1 MRI in vitro experiments were investigated with a 3.0 $\mathrm{T}$ clinical MRI scanner (Siemens Medical Systems) with the following parameters: echo time $(\mathrm{TE})=2.46 \mathrm{~ms}$, repetition time $(\mathrm{TR})=440 \mathrm{~ms}$, slice thickness $=3$ (1) $\mathrm{mm}$, flip angle 90 $\mathrm{o}$, field of view (FoV) $260 \times 260 \mathrm{~mm} 2$. Aqueous dilutions of samples, dispersed in $0.5 \%$ agarose gel, with different [Mn] were placed in tubes. All MR images were then analyzed by using Syngo fastView software. Relaxivity values of $\mathrm{r} 1$ were calculated by a series of $\mathrm{T} 1$ values, when plotted as $1 / \mathrm{T} 1$ according to different $[\mathrm{Mn}]$. The influences of $\mathrm{Mn}_{3} \mathrm{O}_{4}$ nanocrystals, in culturing cancer cells, on MR signal were also tested. After incubation of a certain amount of $\mathrm{Mn}_{3} \mathrm{O}_{4}$ nanocrystals for different time, the adherent cells were removed by a mild treatment with trypsin and then transferred into tube for MR test.

In-vivo MRI scans were carried out on mice, using special mouse coil (Siemens). The mice were provided by Norman Bethune College of Medicine (Jilin University). All animal studies were conducted under a protocol approved by the institutes of animal care and use committee. The parameters used for T1 imaging were: echo time $(\mathrm{TE})=16 \mathrm{~ms}$, repetition time $(\mathrm{TR})=456 \mathrm{~ms}$, slice thickness $=1 \mathrm{~mm}$, flip angle $90 \mathrm{o}$, field of view (FoV) $143 \times 180 \mathrm{~mm}^{2}$. During MRI test the mouse were anesthetized by introperotoneal injection $(200 \mu \mathrm{L}$ per 100 g) of chloral hydrate $(10 \%)$.

\section{Results and discussion}

MCM-41-based MSN were synthesized via sol-gel chemistry. ${ }^{38}$ The MSN material was then surface-functionalized with carboxylic groups to ensure capping of drug loaded nanochannels (denoted as MSN-COOH). Poorly water-soluble antitumor drug (camptothecin, CPT) was selected as the model drug and loaded into the pores of MSN, and the loading amount was significantly high $(53.2 \mathrm{mg} / \mathrm{g})$ compared to those reported in previous studies. ${ }^{12}$ Meanwhile, manganese oxide nanolids were prepared using a really facile route. Otherwise, hightemperature methods are routinely used to synthesize hydrophobic nanoparticles in the presence of organic surfactants and solvents. ${ }^{39,} 40$ However, hydrophobic nanoparticles thus obtained require tedious and time-consuming ligand exchange approaches to render them water dispersible In this work, no organic capping ligands were needed in the course of synthesis. After treating $\mathrm{Mn}_{3} \mathrm{O}_{4}$ with 3aminopropyltriethoxysilane (APTES), a transparent aqueous solution of amine-functionalized $\mathrm{Mn}_{3} \mathrm{O}_{4}$ nanolids $\left(\mathrm{Mn}_{3} \mathrm{O}_{4}-\mathrm{NH}_{2}\right)$ was obtained. The resulting nanolids were subsequently used to cap CPT loaded MSN-COOH orifices via EDC chemistry, in order to minimize the premature release of a cytotoxic drug. Addition of gate-opening triggers, reducing agents such as GSH or DTT, would then uncap the mesopores by redox assisted dissolution of $\mathrm{Mn}_{3} \mathrm{O}_{4}$, allowing the release of the drug molecules.

To investigate this capped system, scanning electron microscopy (SEM) and transmission electron microscopy (TEM) techniques were first used to determine the interaction between MSN and $\mathrm{Mn}_{3} \mathrm{O}_{4}$ nanocrystals. MSN showed smooth surfaces with diameters of $\sim 100 \mathrm{~nm}$ in SEM micrograph, whereas $2 \mathrm{~nm}$ wide channels were visible in TEM images (Supporting Information Fig. S1a, b). The particle size of $\mathrm{Mn}_{3} \mathrm{O}_{4}-\mathrm{NH}_{2}$ nanocrystals was found to be in 5-7nm range (Supporting Information Fig. S2). After capping, CPT loaded $\mathrm{Mn}_{3} \mathrm{O}_{4} @ \mathrm{MSN}$ nanocarriers acquired a scabrous surface compared to original MSN, as evidenced from both SEM and TEM micrographs due to the presence of studded dark spots, which blocked the nanochannels (Fig. 2a, b, c, d). 
Small and wide angle X-ray diffraction (XRD) analysis is performed to validate the drug loading and pore capping procedures. The intensity of characteristic MCM-41type peak is markedly reduced in drug loaded and $\mathrm{Mn}_{3} \mathrm{O}_{4}$ conjugated nanocarrier $\left(\mathrm{Mn}_{3} \mathrm{O}_{4} @ \mathrm{MSN} @ \mathrm{CPT}\right)$ due to the contrast and
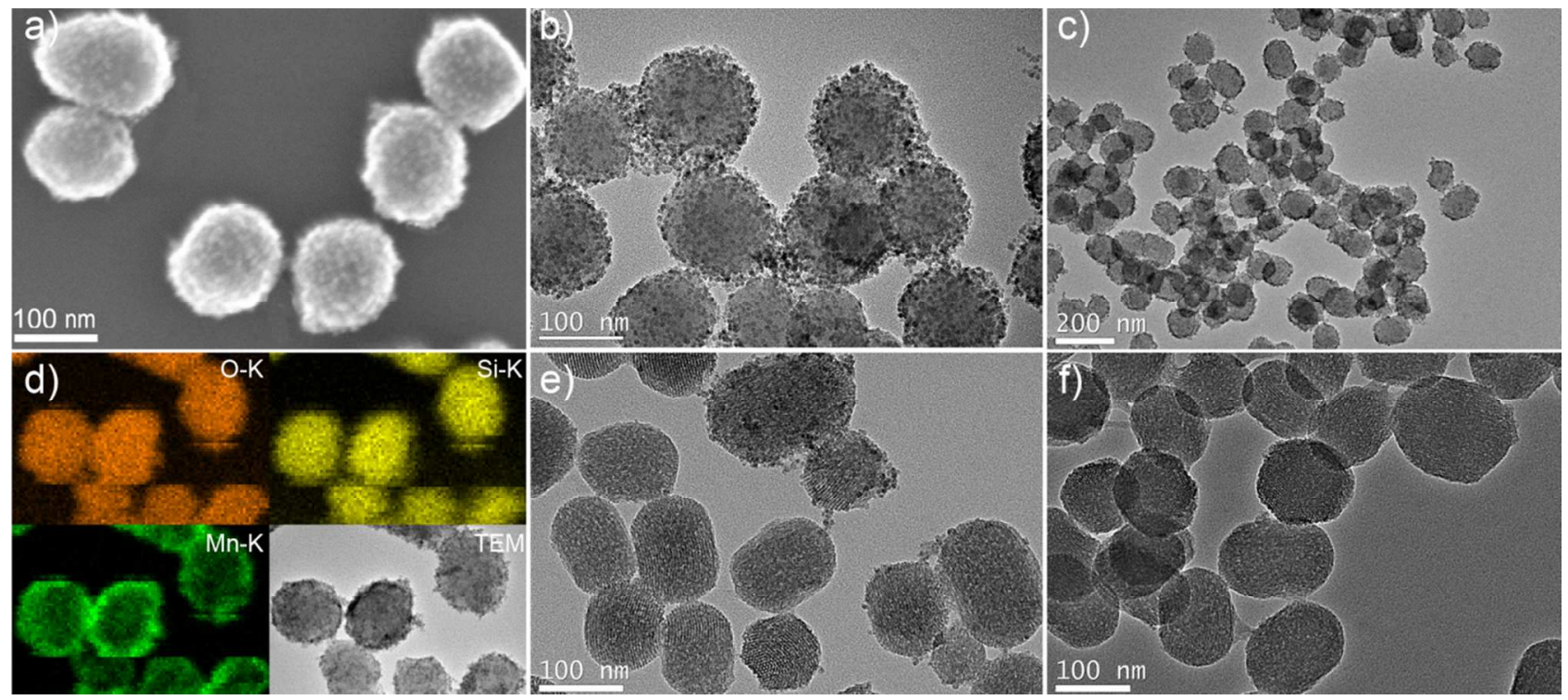

Fig. 2 (a) SEM and (b) (c) TEM micrographs of $\mathrm{Mn}_{3} \mathrm{O}_{4}$ capped MSN. (d) Images of high-angle annular dark-field scanning TEM and energy-dispersive X-ray elemental mapping of $\mathrm{Mn}_{3} \mathrm{O}_{4} @ \mathrm{MSN} @ \mathrm{CPT}$. (e), (f) TEM micrographs of the sample obtained. after incubation in $0.5 \mathrm{mM}$ and $1.0 \mathrm{mM}$ GSH solutions, showing the dissolution of the $\mathrm{Mn}_{3} \mathrm{O}_{4}$ nanolid.

disordered product (Fig. 3f). Figure 3e indicates characteristics peaks of $\mathrm{Mn}_{3} \mathrm{O}_{4}$, the broadness of these peaks can be ascribed to ultrasmall particles size of desired nanolids. Moreover, crystallite size is determined by using Scherer equation. According to XRD data the crystallite size is found to be 7.4 nm. XRD results also validate the conjugation of $\mathrm{Mn}_{3} \mathrm{O}_{4}$ onto the surface of MSN in terms of reduction in the intensity of characteristics $\mathrm{Mn}_{3} \mathrm{O}_{4}$ peaks. X-ray photoelectron spectroscopy (XPS) shed some light on $\mathrm{Mn}_{3} \mathrm{O}_{4}$ and MSN conjugation.

In the survey region (0-1200 eV), carbon, nitrogen, manganese, silicon and nitrogen elements were identified. Since $\mathrm{Mn}_{3} \mathrm{O}_{4}$ nanoparticles are comprised of manganous and manganic ions, so deconvulation of $\mathrm{Mn}$ peak provides two typical peaks at 652.9 and $641.1 \mathrm{eV}$, which are ascribed to $\mathrm{Mn} 2 \mathrm{p}_{1 / 2}$ and $\mathrm{Mn}$ $2 \mathrm{p}_{3 / 2}$ spin-orbit states of $\mathrm{Mn}_{3} \mathrm{O}_{4}$. Energy-dispersive spectroscopy (EDS) also confirms capping of drug loaded nanochannels through $\mathrm{Mn}_{3} \mathrm{O}_{4}$ nanolids. (Fig. S3). $\mathrm{Mn}_{3} \mathrm{O}_{4}-\mathrm{NH}_{2}$ nanocrystals were characterized by Infra-red (IR) (Fig. S4).

Since nitrogen adsorption analysis is usually used to evaluate material in terms of surface area and pore volume, therefore, we have carried out nitrogen adsorption-desorption study to determine the effect of drug loading and pore capping on surface area (Fig. S5). The BET surface area is decreased from $893.8 \mathrm{~cm}^{2} \mathrm{~g}^{-1}$ to $728.3 \mathrm{~cm}^{2} \mathrm{~g}^{-1}$ after CPT loading, whereas the pore volume likewise reduced from $0.761 \mathrm{cc} / \mathrm{g}$ to $0.646 \mathrm{cc} / \mathrm{g}$ respectively. Expectedly, the capping step further lowered the surface area and pore volume to $209.3 \mathrm{~cm}^{2} \mathrm{~g}^{-1}, 0.42 \mathrm{cc} / \mathrm{g}$ respectively.

This study is particularly interesting in term of reductioninduced dissolution of paramagnetic nanolids from the surface of drug loaded mesopores. GSH is a common reducing agent within cells. However, compared to those in normal tissue, GSH levels in human cancer tissues such as breast, ${ }^{41-43}$ colon, ${ }^{44}$ and lung ${ }^{45,46}$ are demonstrated to be fairly high. Both DTT and GSH, commonly used reducing agent, were used in this study as an external stimulus model for the reducing environment of the cytoplasm. Since $\mathrm{Mn}_{3} \mathrm{O}_{4}$ is comprised of both $\mathrm{Mn}(\mathrm{II})$ and $\mathrm{Mn}$ (III) species, it was envisaged that the high intracellular reducing environment in tumor cells reduced $\mathrm{Mn}$ (III) into manganese (II), thus disintegrating the $\mathrm{Mn}_{3} \mathrm{O}_{4}$ solid nanoparticles into water soluble Mn (II) ions. 


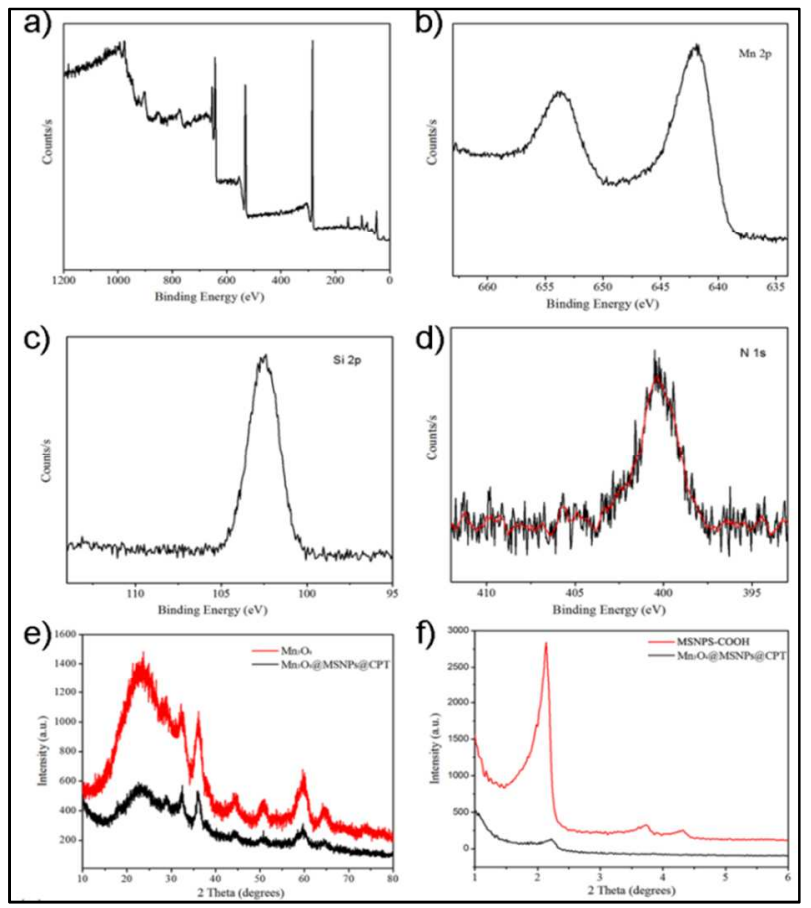

Fig. 3 (a), (b), (c), (d) XPS spectrum of $\mathrm{Mn}_{3} \mathrm{O}_{4} @$ MSN nanocomposite. (a) Full survey spectrum, (b) Mn 2p peak, (c) Si 2p peak, (d) N 1s peak. (e) Wide-angle $\mathrm{Mn}_{3} \mathrm{O}_{4} @ \mathrm{MSN}$ and $\mathrm{Mn}_{3} \mathrm{O}_{4}$ nanocrystal peaks. (f) Low-angle X-ray diffraction (XRD) patterns of $\mathrm{Mn}_{3} \mathrm{O}_{4} @ \mathrm{MSN}$ and MSN-COOH peaks.

As a proof-of-concept study to validate reduction induced dissolution of paramagnetic "gatekeeper", we dispersed $\mathrm{Mn}_{3} \mathrm{O}_{4} @ \mathrm{MSN} @ \mathrm{CPT}$ or $\mathrm{Mn}_{3} \mathrm{O}_{4}$ nanocrystals in phosphatebuffered saline (PBS) solution containing DTT and GSH at various concentrations (Fig. 4a, b). Notably, these in vitro experiments furnishes an opprotunity to gain some insight about the dissolution control drug release mechanism, moreover, we can predict a similar in vivo drug release behavior after redox mediated dissoluion of magnetic nanolids. In the absence of any reducing agents, a flat baseline was obtained, and less than $6 \% \mathrm{CPT}$ was leached from drug formulation. In contrast, with the introduction of DTT or GSH of different amounts, CPT release profile displayed an obvious increasing trend, suggesting the dissolution of $\mathrm{Mn}_{3} \mathrm{O}_{4}$ to unleash the loaded drug molecules. The dissolution process of $\mathrm{Mn}_{3} \mathrm{O}_{4}$ was also verified by the gradual disappearance of the dark dots from MSN surface as revealed in TEM images (Fig. 2e, $\mathrm{f}$ and Supporting Information Fig. S1a,b).

Incubation of capped sample in the presence of reducing agents of different kinds and concentrations led to a more revealing and convincing proof of $\mathrm{Mn}_{3} \mathrm{O}_{4}$ disintegration. Significant fading of dark brown colour of $\mathrm{Mn}_{3} \mathrm{O}_{4}$ was observed along with increasing time and concentration of GSH (Fig. 4c). To further evaluate our hypothesis of redox-induced dissolution, inductively coupled plasma (ICP) analysis was carried out to detect the concentration of manganese ions after subjecting $\mathrm{Mn}_{3} \mathrm{O}_{4}$ to different concentration of GSH (Fig. 4d). It was found that there was no manganese ions leached out within $12 \mathrm{~h}$ in the absence of GSH treatment. However, treatment of $\mathrm{Mn}_{3} \mathrm{O}_{4}$ nanocrystals with GSH resulted in increasing concentration of manganese ions, which lend strong support to our proposed ideas that manganese ions leached from $\mathrm{Mn}_{3} \mathrm{O}_{4}$ into liquid phase gradually.
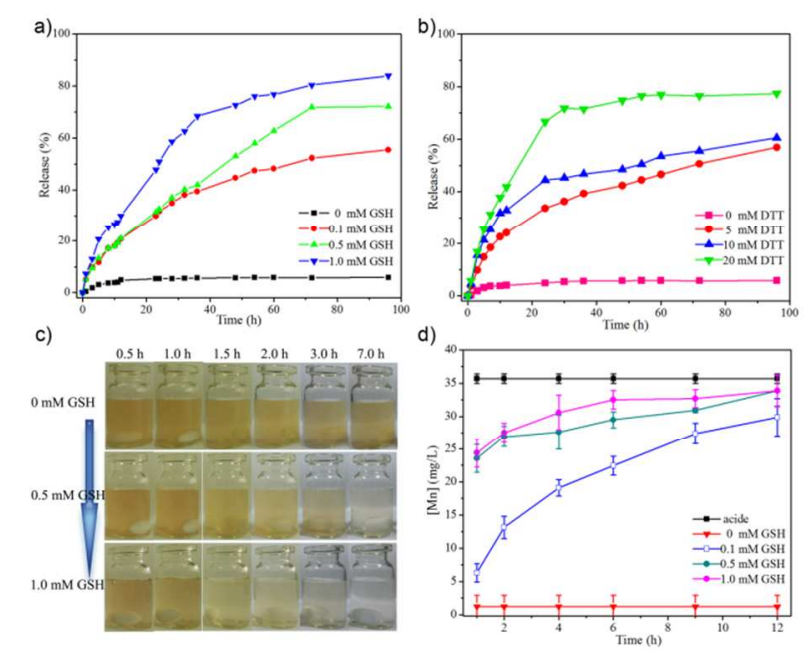

Fig. 4 (a) Release profiles of $\mathrm{Mn}_{3} \mathrm{O}_{4} @ \mathrm{MSN} @ \mathrm{CPT}$ formulation in 0, 0.1, 0.5, 1.0 $\mathrm{mM}$ of GSH. (b) Release profiles of $\mathrm{Mn}_{3} \mathrm{O}_{4} @ \mathrm{MSN} @ \mathrm{CPT}$ in $0,5,10,20 \mathrm{mM}$ of DTT. (c) Photographs of $\mathrm{Mn}_{3} \mathrm{O}_{4} @ \mathrm{MSN}$ incubated in different concentration of $\mathrm{GSH}$, confirming the dissolution of paramagnetic nanocrystals (d) inductively coupled plasma (ICP) analysis after subjecting $\mathrm{Mn}_{3} \mathrm{O}_{4}$ nanocrystals to different concentration of GSH.

Raman spectra of GSH, oxidized glutathione (GSSG) and the final product of $\mathrm{Mn}_{3} \mathrm{O}_{4}$ dissolution in GSH solution respectively were shown in Fig. 5. A characteristic band at $2579 \mathrm{~cm}^{-1}$ (S-H stretching) was observed in mere glutathione sample; however, after the addition of $\mathrm{Mn}_{3} \mathrm{O}_{4}$ solution the thiol $(\mathrm{S}-\mathrm{H})$ peak was disappeared and subsequently a new band at $511 \mathrm{~cm}^{-1}$ (S-S stretching) was appeared, demonstrating the dimerization of glutathione. More importantly, the typical $\mathrm{Mn}_{3} \mathrm{O}_{4}$ peak $(\sim 650$ $\mathrm{cm}^{-1}$ ) is absent after the exposure of GSH, thus establishing the dissolution of $\mathrm{Mn}_{3} \mathrm{O}_{4}$. Two prominent peaks at $3404 \mathrm{~cm}^{-1}$ and $3422 \mathrm{~cm}^{-1}$ are ascribed $\mathrm{N}-\mathrm{H}$ stretching, derived from amine moiety of APTES. This result indicates the GSH molecules are oxidized after reacting with $\mathrm{Mn}_{3} \mathrm{O}_{4}$. It also sheds some light on mechanism and suggests that $\mathrm{Mn}_{3} \mathrm{O}_{4}$ dissolution was carried out via thiol-disulfide transformation, and resultantly GSSG is produced as shown in the equation (Figure 5). ${ }^{47}$ 

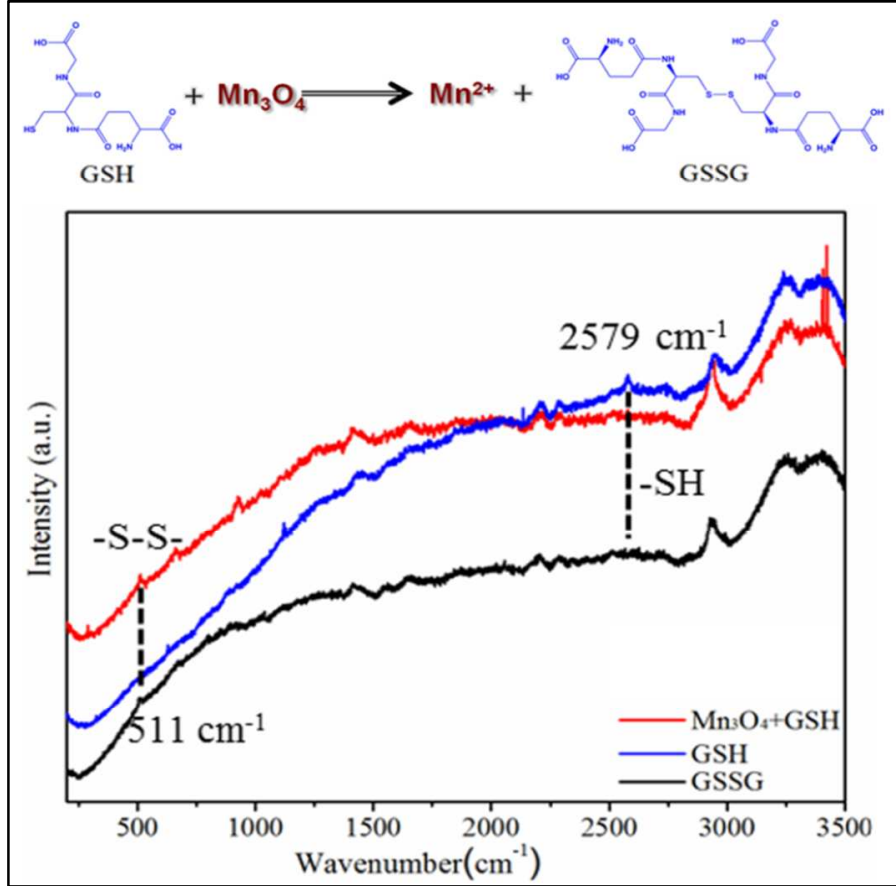

Fig. 5 Schematic diagram shows the dimerization of glutathione after reacting with $\mathrm{Mn}_{3} \mathrm{O}_{4}$ nanopartices and the Raman spectra of GSH, GSSG and GSH after treatment with $\mathrm{Mn}_{3} \mathrm{O}_{4}$ nanocrystals.

In order to assess the biological properties of our capping system, MTT assay was performed by using pancreatic cancer cells (BxPC-3) (Fig. 6a, b, c). The cytotoxicity of $\mathrm{Mn}^{2+}$ ions (as $\left.\mathrm{MnCl}_{2}\right), \mathrm{Mn}_{3} \mathrm{O}_{4}$ nanocrystals, capping sample and free CPT was estimated. Firstly, the cytotoxicity of $\mathrm{Mn}_{3} \mathrm{O}_{4}$ nanocrystals, manganese ion and $\mathrm{Mn}_{3} \mathrm{O}_{4} @ \mathrm{MSN}$ were compared, which showed that all species displayed a similar cell viability performance at low concentration. However, at high equivalent concentration, $\mathrm{Mn}_{3} \mathrm{O}_{4}$ nanocrystals exhibited fairly low cytotoxicity compared with $\mathrm{Mn}^{2+} \cdot \mathrm{Mn}_{3} \mathrm{O}_{4} @ \mathrm{MSN}$ shows the same behavior with $\mathrm{Mn}_{3} \mathrm{O}_{4}$ nanocrystals. Based on these results, we supposed that the relatively high levels of intracellular reducing agents lead to slow disintegration of $\mathrm{Mn}_{3} \mathrm{O}_{4}$ to yield cytotoxic $\mathrm{Mn}^{2+}$ ions, as was proved by the high killing 


\section{ARTICLE}
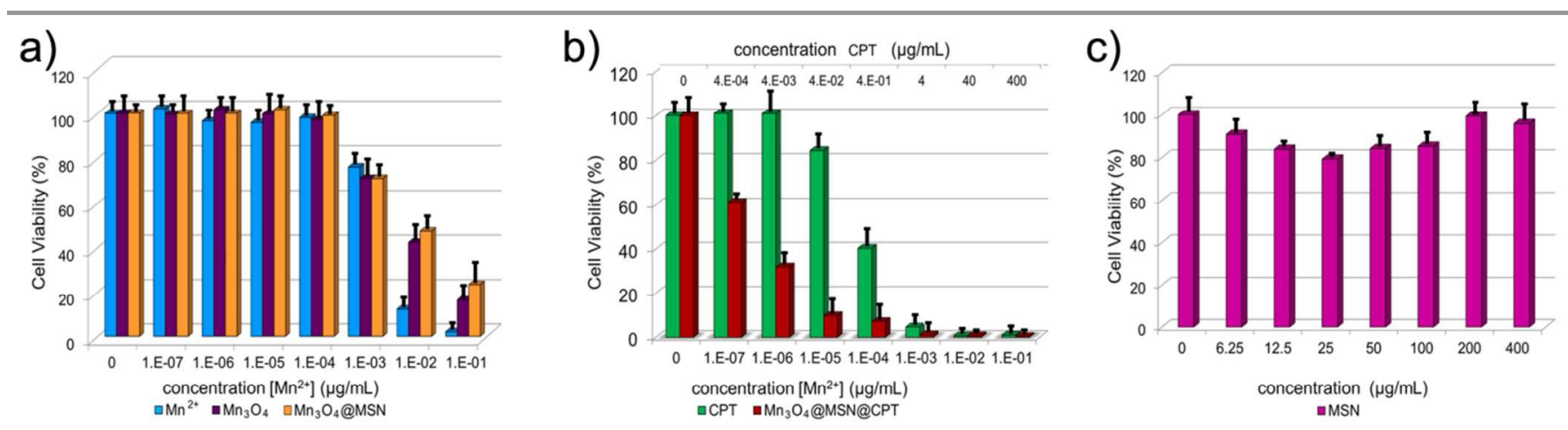

d)
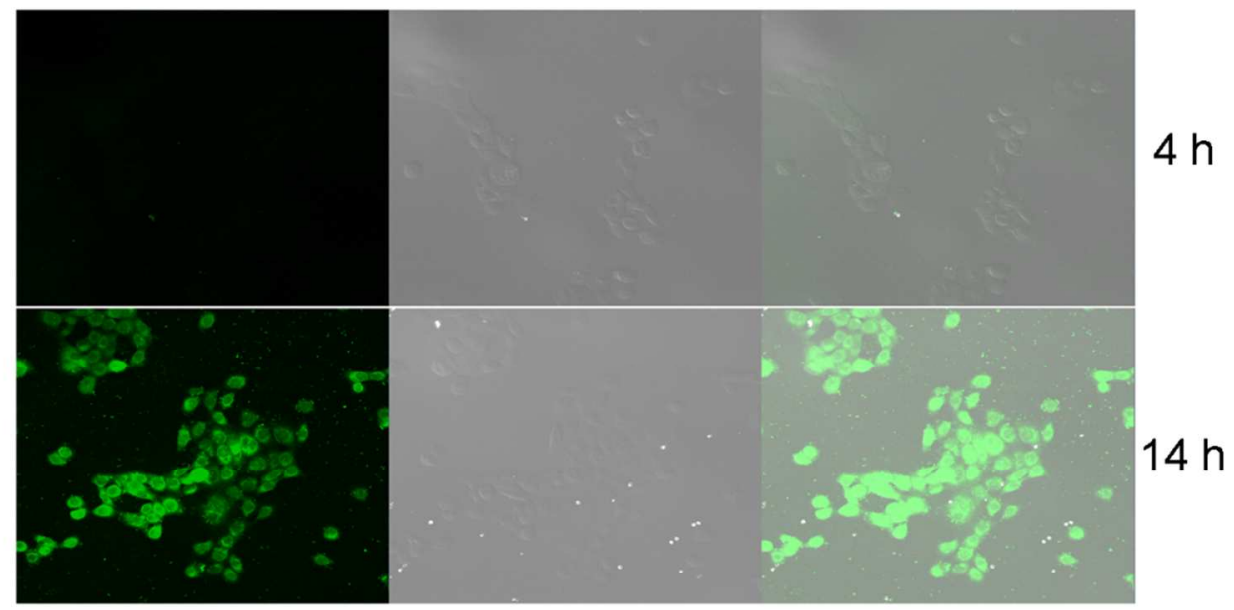

Fluorescent

Bright

Merged

Fig. 6 (a) In vitro viability of $\mathrm{BxPC}-3$ cells in the presence of $\mathrm{Mn}^{2+}, \mathrm{Mn}_{3} \mathrm{O}_{4}$ nanolids and $\mathrm{Mn}_{3} \mathrm{O}_{4} @ \mathrm{MSN}$, (b) Mn $3 \mathrm{O}_{4} @ \mathrm{MSN} @ \mathrm{CPT}$, free CPT, And (c) MSN functionalized with carboxyl groups, incubation time was $72 \mathrm{~h}$. Values are the average of three separate experiments in triplicate and are expressed as mean $+\square$ SD. $* p$ $<\square 0.05$. (d) Fluorescence confocal images of " $\mathrm{Mn}_{3} \mathrm{O}_{4} @ \mathrm{MSN} @$ rhodamine 6G" nanoparticles and their uptake by BxPC-3 cancer cells in different time. No obvious fluorescence was observed within the cells wath 4 incubated

efficiency of manganese ions compared to $\mathrm{Mn}_{3} \mathrm{O}_{4}$ nanocrystals at low concentrations.

Therefore, we can infer that $\mathrm{Mn}_{3} \mathrm{O}_{4}$ nanocrystal itself exhibits no cytotoxicity until transformed into manganese ion. Expectedly, drug loaded $\mathrm{Mn}_{3} \mathrm{O}_{4} @ \mathrm{MSN}$ exhibited much higher cytotoxic effect on pancreatic cancer cells growth and proliferation than that observed with equivalent dose of free CPT in the culture medium. When the drug formulation displayed potent cytotoxic activity at the therapeutic concentration, the $\mathrm{Mn}_{3} \mathrm{O}_{4}$ nanolids exhibited no cytotoxic potential, which proved the biocompatibility of $\mathrm{Mn}_{3} \mathrm{O}_{4}$ nanocrystals. The improvement of the cell inhibitory performance of hydrophobic CPT should be credited to hydrophilic mesoporous nanocarriers which not only ensured the controlled release of water insoluble CPT, but also realized a highly needed site specific targeted drug release.
To visualize in vitro dissolution and encapsulated cargo release, confocal microscopy was checked by loading rhodamine $6 \mathrm{G}$ as a model dye. Fig. 6d shown the confocal images of BxPC-3 cells treated with differentnt rhodamine $6 \mathrm{G}$ loaded $\mathrm{Mn}_{3} \mathrm{O}_{4} @ \mathrm{MSN}$ nanoformulations in different times (4 h and 12 h), whereas working parameters remains constant in every experiment. Four hours incubation resulted in a negligible staining of cancer cells, however, after $12 \mathrm{~h}$ incubation a significant increase in the fluorescence of Rhodamine $6 \mathrm{G}$ was observed. Initially, most of the nanolids were intact and rhodamine $6 \mathrm{G}$ molecules were still confined inside the MSN within $4 \mathrm{~h}$, but prolonged incubation time permits responsive and sustained release of the cargo into cell. Taken together, cell micrographs varifies the slow dissolution of the $\mathrm{Mn}_{3} \mathrm{O}_{4}$ nanocrystals and subsequent sustained release of drug over the period of time. 
As $\mathrm{Mn}_{3} \mathrm{O}_{4}$ exhibits $\mathrm{T} 1$ effects, utilization of drug loaded paramagnetic nanocrystals capped MSN as T1 MRI contrast agent is indeed a judicious choice to be executed. To evaluate the effectiveness of $\mathrm{Mn}_{3} \mathrm{O}_{4} @ \mathrm{MSN} @ \mathrm{CPT}$ as MRI contrast agents, in vitro experiments were performed. Fig. 7a, b, c showed the capping sample when subjected to T1 MRI. As the concentration of manganese was increased, enhancement in the magnetic resonance signal was observed, thus establishing its potential application as a $\mathrm{T} 1$ contrast agent. The relaxivity value ( $\mathrm{r} 1$ ) of the NPs was found to be $13.39 \mathrm{mM}^{-1} \mathrm{~s}^{-1}$. It was interesting to note that after the disintegration of the capping agent $\left(\mathrm{Mn}_{3} \mathrm{O}_{4}\right.$ nanolids) by $\mathrm{GSH}$, the signals of magnetic resonance were greatly improved and $\mathrm{r} 1$ value was almost 2 times increased to $25.17 \mathrm{mM}^{-1} \mathrm{~s}^{-1}$. This phenomenon can be explained by redox-mediated leaching of manganese ions from $\mathrm{Mn}_{3} \mathrm{O}_{4}$. The resulting free manganese ions can readily interact with nearby water molecules to enhance T1 signal. To decide the biological applicability of this system, in vitro cell study was also performed (Fig. 7d). The incubation of $\mathrm{Mn}_{3} \mathrm{O}_{4}$ nanocrystals with BxPC-3 cells led to a pronounced increase in T1 signal with increasing incubation time. In vitro cell study also suggested that cancer cells are capable of dissolving $\mathrm{Mn}_{3} \mathrm{O}_{4}$ nanocrystals at a steady rate, because of high intracellular GSH concentration. Moreover, we extended the system to in vivo environment, and carried out MR test by in vivo injection of nanoformulation ( $2 \mathrm{mg}$ of $\mathrm{Mn}$ per $\mathrm{kg}$ of mouse body weight). As a result, series of $\mathrm{T} 1$ images were obtained as shown in Fig. 7e. In comparison with pre-contrast images, an obvious signal enhancement both in kidney and liver was noticed with increasing time, indicating the potential utility of our strategy.

a)

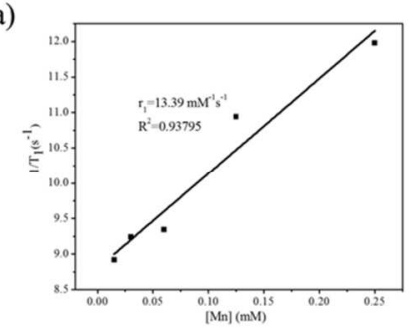

c)
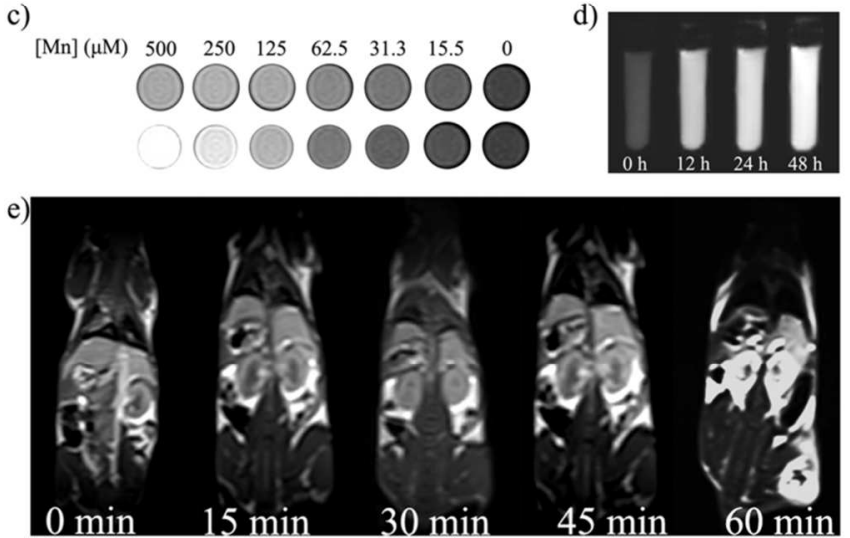

Fig. 7 (a) Before and (b) after the dissolution of $\mathrm{Mn}_{3} \mathrm{O}_{4}$ nanocrystals, T1 relaxation rate plots rate (1/T1) of versus of $\mathrm{Mn}$ Concentration. (c) Before (top panel) and after (down panel) the dissolution of $\mathrm{Mn}_{3} \mathrm{O}_{4} \mathrm{~T} 1$ weighted MR images of dispersed $\mathrm{Mn}_{3} \mathrm{O}_{4} @ \mathrm{MSN}$ at different Mn concentrations in $0.5 \%$ agarose. (d) In vitro cell study of $\mathrm{Mn}_{3} \mathrm{O}_{4} @ \mathrm{MSN}$ incubated in BxPC-3 cells with different incubation time (with $\mathrm{Mn}$ concentration $0.1 \mu \mathrm{g} / \mathrm{mL}$ ). (e) A series of $3.0 \mathrm{~T}$ in vivo T1 MRI of a mouse with time after injection of a $\mathrm{Mn}_{3} \mathrm{O}_{4} @ \mathrm{MSN}$ solution into a mouse tail vein.

\section{Conclusions}

In conclusion, we have developed a sophisticated nanotheranostic system, using $\mathrm{Mn}_{3} \mathrm{O}_{4}$ nanoparticles to cap drug loaded channels of mesoporous silica for simultaneously performing intelligent drug delivery and redox-activated contrast-enhanced MRI. Manganese oxide nanoparticles are demonstrated to be highly susceptible to intracellular redox environment, and readily undergo dissolution when exposed to highly prevalent intracellular reducing agent glutathione. As a result, channels of silica are opened to release loaded drug molecules, leading to target specific therapeutic response against cancer cells. Most prominently, redox assisted dissolution of $\mathrm{Mn}_{3} \mathrm{O}_{4}$ nanolids to manganese ions also led to twofold increase in $\mathrm{T} 1$ signal. We envision that our results would prove a significant step in personalized medicine and provide a synergistic strategy to enhance therapeutic and imaging efficiency.

\section{Acknowledgements}

We are grateful to the financial support from National Basic Research Program of China (973 Program, grant nos.2012CB821700), Major International (Regional) Joint Research Project of NSFC (grant nos. 21120102034) NSFC(grant nos.20831002) and Australian Research Council Future Fellowship (FT100101059).

\section{Notes and references}

a State Key Laboratory of Inorganic Synthesis and Preparative Chemistry, College of Chemistry, Jilin University, Changchun, 130012, China, Fax: (+86) 431-516-8331, Tel: (+86) 431-516-8331, E-mail: zhugs@jlu.edu.cn

${ }^{\mathrm{b}}$ Queensland Micro- and Nanotechnology Centre, Griffith University, Nathan QLD 4111, Australia.

c Radiology Department, The First Hospital of Jilin University, Changchun,130021, China

${ }^{\mathrm{d}}$ College of Life Science, Jilin University, Changchun,130012, China

${ }^{\mathrm{e} C}$ College of Construction Engineering, Jilin University, Changchun, 130026

Corresponding author: Email address: zhugs@jlu.edu.cn

Electronic Supplementary Information (ESI) available: See DOI: $10.1039 / \mathrm{b} 000000 \mathrm{x} /$

1. M. E. Davis, Z. Chen and D. M. Shin, Nat. Rev. Drug Discov., 2008, 7, 771-782.

2. L. Zhang, F. X. Gu, J. M. Chan, A. Z. Wang, R. S. Langer and O. C. Farokhzad, Clin. Pharmacol. Ther., 2007, 83, 761-769.

V. R. Devadasu, V. Bhardwaj and M. N. V. R. Kumar, Chem. Rev., 2012, 113, 1686-1735.

D. Peer, J. M. Karp, S. Hong, O. C. Farokhzad, R. Margalit and R.

5. Langer, Nat. Nano., 2007, 2,751-760. Santamaría, Nano Today, 2007, 2, 22-32. 
6. I. Meerovich, A. Koshkaryev, R. Thekkedath and V. P. Torchilin, 36. Bioconjugate Chem., 2011, 22, 2271-2282.

7. Q. Huo, J. Liu, L.-Q. Wang, Y. Jiang, T. N. Lambert and E. Fang, J. Am. Chem. Soc., 2006, 128, 6447-6453.

8. L. M. Kaminskas, V. M. McLeod, B. D. Kelly, C. Cullinane, G. Sberna, M. Williamson, B. J. Boyd, D. J. Owen and C. J. H. Porter, Mol. Pharm., 2012, 9, 422-432.

9. W. Wu, S. Wieckowski, G. Pastorin, M. Benincasa, C. Klumpp, J.-P. Briand, R. Gennaro, M. Prato and A. Bianco, Angew. Chem. Int. Ed., 2005, 44, 6358-6362.

10. N. Chanda, V. Kattumuri, R. Shukla, A. Zambre, K. Katti, A. Upendran, R. R. Kulkarni, P. Kan, G. M. Fent, S. W. Casteel, C. J. Smith, E. Boote, J. D. Robertson, C. Cutler, J. R. Lever, K. V. Katti and R. Kannan, PNAS, 2010, 107, 8760-8765.

11. M. Liong, J. Lu, M. Kovochich, T. Xia, S. G. Ruehm, A. E. Nel, F. Tamanoi and J. I. Zink, ACS NANO, 2008, 2, 889-896.

12. J. Lu, M. Liong, J. I. Zink and F. Tamanoi, Small, 2007, 3, 13411346.

13. I. I. Slowing, J. L. Vivero-Escoto, C.-W. Wu and V. S. Y. Lin, Adv. Drug Deliv. Rev., 2008, 60, 1278-1288.

14. V. Cauda, C. Argyo, A. Schlossbauer and T. Bein, J. Mater. Chem., 2010, 20, 4305-4311.

15. R. Liu, Y. Zhang, X. Zhao, A. Agarwal, L. J. Mueller and P. Y. Feng, J. Am. Chem. Soc., 2010, 132, 1500-1501.

16. H. P. Rim, K. H. Min, H. J. Lee, S. Y. Jeong and S. C. Lee, Angew. Chem. Int. Ed., 2011, 50, 8853-8857.

17. C. Y. Lai, B. G. Trewyn, D. M. Jeftinija, K. Jeftinija, S. Xu, S. Jeftinija and V. S. Y. Lin, J. Am. Chem. Soc., 2003, 125, 44514459.

18. X. Ma, K. T. Nguyen, P. Borah, C. Y. Ang and Y. L. Zhao, $A d v$. Healthcare Mater., 2012, 1, 690-697.

19. N. Mas, A. Agostini, L. Mondragon, A. Bernardos, F. Sancenon, M. D. Marcos, R. Martinez-Manez, A. M. Costero, S. Gil, M. Merino-Sanjuan, P. Amoros, M. Orzaez and E. Perez-Paya, Chem. Eur. J., 2013, 19, 1346-1356.

$20 . \quad$ J. Zhang, Z.-F. Yuan, Y. Wang, W.-H. Chen, G.-F. Luo, S.-X. Cheng, R.-X. Zhuo and X.-Z. Zhang, J. Am. Chem. Soc., 2013, 135, 5068-5073.

21. D. P. Ferris, Y.-L. Zhao, N. M. Khashab, H. A. Khatib, J. F. Stoddart and J. I. Zink, J. Am. Chem. Soc., 2009, 131, 1686-1688.

22. Q. Yuan, Y. Zhang, T. Chen, D. Lu, Z. Zhao, X. Zhang, Z. Li, C.H. Yan and W. Tan, ACS NANO, 2012, 6, 6337-6344.

23. A. Schlossbauer, J. Kecht and T. Bein, Angew. Chem. Int. Ed., 2009, 48, 3092-3095.

$24 . \quad$ C. R. Thomas, D. P. Ferris, J.-H. Lee, E. Choi, M. H. Cho, E. S. Kim, J. F. Stoddart, J.-S. Shin, J. Cheon and J. I. Zink, J. Am. Chem. Soc., 2010, 132, 10623-10625.

25. Y. Zhu, H. Liu, F. Li, Q. Ruan, H. Wang, M. Fujiwara, L. Wang and G. Q. Lu, J. Am. Chem. Soc., 2010, 132, 1450-1451.

26. F. Muharnmad, M. Y. Guo, W. X. Qi, F. X. Sun, A. F. Wang, Y. J. Guo and G. S. Zhu, J. Am. Chem. Soc., 2011, 133, 8778-8781.

27. G. Zhang, Y. Liu, Q. Yuan, C. Zong, J. Liu and L. Lu, Nanoscale, 2011, 3, 4365-4371.

28. W. Zhang, X.-W. He, Y.-Q. Yang, W.-Y. Li and Y.-K. Zhang, J. Mater. Chem. B, 2013, 1, 347-352.

29. K. Ma, H. Sai and U. Wiesner, J. Am. Chem. Soc., 2012, 134, 13180-13183.

30. H. Yang, Y. Zhuang, H. Hu, X. Du, C. Zhang, X. Shi, H. Wu and S. Yang, Adv. Funct. Mater., 2010, 20, 1733-1741.

31. J. J. Davis, W.-Y. Huang and G.-L. Davies, J. Mater. Chem., 2012, 22, 22848-22850.

32. B. Chang, J. Guo, C. Liu, J. Qian and W. Yang, J. Mater. Chem., 2010, 20, 9941-9947.

33. J. E. Lee, N. Lee, H. Kim, J. Kim, S. H. Choi, J. H. Kim, T. Kim, I. C. Song, S. P. Park, W. K. Moon and T. Hyeon, J. Am. Chem. Soc., 2010, 132, 552-557.

34. J. Kim, H. S. Kim, N. Lee, T. Kim, H. Kim, T. Yu, I. C. Song, W. K. Moon and T. Hyeon, Angew. Chem. Int. Ed., 2008, 47, 84388441.

35. T. Kim, E. Momin, J. Choi, K. Yuan, H. Zaidi, J. Kim, M. Park, N. Lee, M. T. McMahon, A. Quinones-Hinojosa, J. W. M. Bulte, T. Hyeon and A. A. Gilad, J. Am. Chem. Soc., 2011, 133, 29552961.
H. Hu, A. Dai, J. Sun, X. Li, F. Gao, L. Wu, Y. Fang, H. Yang, L. An, H. Wu and S. Yang, Nanoscale, 2013, 5, 10447-10454.

$\begin{array}{ll}37 . & \text { F. Hu and Y. S. Zhao, Nanoscale, 2012, 4, 6235-6243. } \\ 38 . & \text { C.-Y. Lai, B. G. Trewyn, D. M. Jeftinija, K. Jeftinija, S. Xu, S. }\end{array}$ Jeftinija and V. S. Y. Lin, J. Am. Chem. Soc., 2003, 125, 44514459.

39. T. Kim, E.-J. Cho, Y. Chae, M. Kim, A. Oh, J. Jin, E.-S. Lee, H. Baik, S. Haam, J.-S. Suh, Y.-M. Huh and K. Lee, Angew. Chem. Int. Ed., 2011, 50, 10589-10593.

$40 . \quad$ H. B. Na, J. H. Lee, K. An, Y. I. Park, M. Park, I. S. Lee, D.-H. Nam, S. T. Kim, S.-H. Kim, S.-W. Kim, K.-H. Lim, K.-S. Kim, S.-O. Kim and T. Hyeon, Angew. Chem., 2007, 119, 5493-5497.

41. M. Raderer and W. Scheithauer, Cancer, 1993, 72, 3553-3563.

42. R. R. Perry, J. Mazetta, M. Levin and S. C. Barranco, Cancer, 1993, 72, 783-787.

43. K. Lee, H. Lee, K. H. Bae and T. G. Park, Biomaterials, 2010, 31, 6530-6536.

44. S. M. S. Redmond, F. Joncourt, K. Buser, A. Ziemiecki, H.-J. Altermatt, M. Fey, G. Margison and T. Cerny, Cancer Research, 1991, 51, 2092-2097.

45. J. A. Cook, H. I. Pass, S. N. Iype, N. Friedman, W. DeGraff, A. Russo and J. B. Mitchell, Cancer Research, 1991, 51, 4287-4294. T. Schnelldorfer, S. Gansauge, F. Gansauge, S. Schlosser, H. G. Beger and A. K. Nussler, Cancer, 2000, 89, 1440-1447.

47. S. Kumar, W.-K. Rhim, D.-K. Lim and J.-M. Nam, ACS NANO, 2013, 7, 2221-2230 
Table of Contents

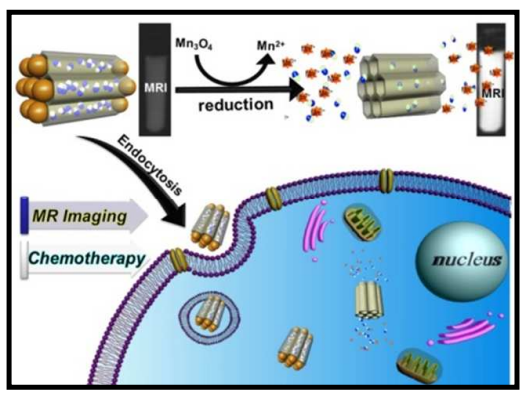

Redox sensitive dissolution of paramagnetic NPs $\left(\mathrm{Mn}_{3} \mathrm{O}_{4}\right)$ results in a controlled drug release and enhanced magnetic resonance imaging. 

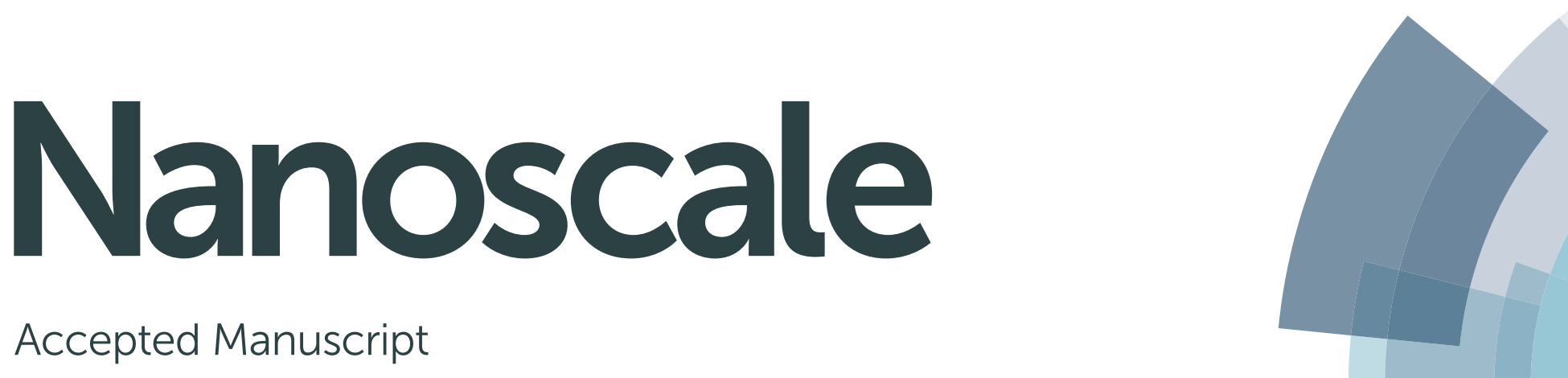

\section{Accepted Manuscript}

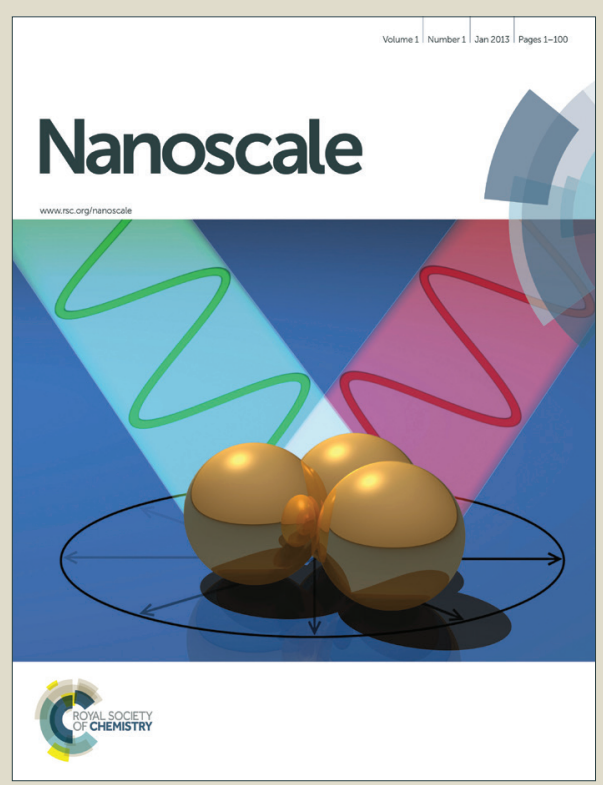

This is an Accepted Manuscript, which has been through the Royal Society of Chemistry peer review process and has been accepted for publication.

Accepted Manuscripts are published online shortly after acceptance, before technical editing, formatting and proof reading. Using this free service, authors can make their results available to the community, in citable form, before we publish the edited article. We will replace this Accepted Manuscript with the edited and formatted Advance Article as soon as it is available.

You can find more information about Accepted Manuscripts in the Information for Authors.

Please note that technical editing may introduce minor changes to the text and/or graphics, which may alter content. The journal's standard Terms \& Conditions and the Ethical guidelines still apply. In no event shall the Royal Society of Chemistry be held responsible for any errors or omissions in this Accepted Manuscript or any consequences arising from the use of any information it contains. 